\title{
FAKTOR - FAKTOR YANG MEMPENGARUHI KEPATUHAN PASIEN GAGAL GINJAL KRONIS YANG MENJALANI HEMODIALISIS DI RSUD GUNUNGSITOLI NIAS
}

\author{
Edriyani Yonlafado Simanjuntak, Bangun Andi Syahputra Halawa \\ Universitas Sari Mutiara Indonesia \\ Email : edriyani260481@gmail.com,bhalawa93@yahoo.com
}

\begin{abstract}
One of the non-communicable diseases in the world about health problem is chronic kidney failure. Adherence is required in the management process of hemodialysis to achieve a better quality of life. Noncompliance cause emergency complications that affect the quality of life of patients. The purpose of this study was to determine the factors that influence the compliance of patients with chronic kidney disease undergoing hemodialysis in the RSUD Gunungsitoli Nias. This study used a comparative analytic design with a crossectional study design. The population of this study was patients with Chronic Kidney Disease who underwent hemodialysis therapy at the Hemodialysis Unit of the Gunungsitoli General Hospital in Nias with data collection techniques using accidental sampling technique with a total sample of 48 people. The data collection tool uses questionnaire instruments and statistical tests using the Person Chi-Square Test. The results showed the majority of age factors were 31-40 years (62.5\%), the majority of the distance $\geq 3 \mathrm{~km}(68.8 \%)$, the income of the majority was high (41.7\%), the motivation of the majority was high (68.8\%), support the majority of the family is good (50\%) and the majority compliance is obedient (66.7\%). Person Chi-Square test shows age $(p=0.407)$, distance $(p=0.509)$ and motivation $(p=0.186)$ and income factors $(p=$ $0.001)$ and family support $(p=0,000)$. The conclusion of this study is that age, distance and motivation factors influence adherence while income and family support factors influence adherence in patients with chronic renal failure undergoing hemodialysis in Gunungsitoli Nias General Hospital. It is recommended to families and health workers to provide support to family members who undergoing hemodialysis and always accompany and encourage them to undergo hemodialysis, for patients to improve adherence to hemodialysis therapy to improve quality of life.
\end{abstract}

Keywords: Compliance, chronic kidney disease, hemodialysis

\begin{abstract}
Abstrak
Salah satu penyakit tidak menular menjadi permasalahan kesehatan dunia adalah gagal ginjal kronis. Diperlukan kepatuhan dalam proses penatalaksanaan hemodialisis untuk mencapai kualitas hidup yang lebih baik. Ketidakpatuhan menimbulkan komplikasi kegawatan berdampak pada kualitas hidup pasien. Tujuan penelitian ini adalah untuk mengetahui faktor - faktor yang mempengaruhi kepatuhan pasien Gagal ginjal kronis yang menjalani hemodialisis di RSUD Gunungsitoli Nias. Penelitian ini menggunakan desain analitik komparatif dengan rancangan penelitian crossectional study. Populasi penelitian ini adalah pasien Gagal Ginjal Kronis yang menjalani terapi hemodialisis di Unit Hemodialisis Rumah Sakit Umum Daerah Gunungsitoli Nias dengan teknik pengambilan data menggunakan teknik accidental sampling dengan jumlah sampel didapatkan sebanyak 48 orang. Alat pengumpulan data menggunakan instrumen kuesioner dan uji satatistik menggunakan Person Chi-Square Test. Hasil penelitian menunjukkan faktor usia mayoritas 31-40 tahun $(62,5 \%)$, jarak mayoritas $\geq 3 \mathrm{~km}$ $(68,8 \%)$, pendapatan mayoritas tinggi $(41,7 \%)$, motivasi mayoritas tinggi $(68,8 \%)$, dukungan keluarga mayoritas baik (50\%) dan kepatuhan mayoritas patuh (66,7\%). Uji Person Chi-Square menunjukkan faktor usia $(\mathrm{p}=0,407)$, jarak $(\mathrm{p}=0,509)$ dan motivasi $(\mathrm{p}=0.186)$ dan faktor pendapatan $(\mathrm{p}=0.001)$ dan dukungan keluarga $(\mathrm{p}=0,000)$. Kesimpulan penelitian ini adalah faktor usia, jarak dan motivasi mempengaruhi kepatuhan sedangkan faktor pendapatan dan dukungan keluarga mempengaruhi kepatuhan pada pasien gagal ginjal kronis yang menjalani hemodialisis di RSUD Gunungsitoli Nias. Disarankan kepada keluarga dan petugas kesehatan dapat memberikan dukungan kepada anggota keluarga yang menjalani hemodialisa dan selalu mendampingi serta memberi semangat dalam menjalani
\end{abstract}


hemodialisis, Bagi pasien agar meningkatkan kepatuhan akan terapi hemodialisis untuk meningkatkan kualitas hidup.

Kata Kunci : Kepatuhan, gagal ginjol kronik, hemodialis

\section{PENDAHULUAN}

Salah satu penyakit tidak menular menjadi permasalahan kesehatan dunia adalah gagal ginjal kronis. Menurut Kemenkes RI dalam Lestari dan Nurmala (2015) kecenderungan dokter mendiagnosa setelah fungsi ginjal sudah mengalami penurunan sehingga menyebabkan komplikasi seperti masalah kardiovaskuler.

Berdasarkan Badan Kesehatan Dunia (WHO) bahwa peningkatan jumlah penderita gagal ginjal pada tahun 2013 telah meningkat $50 \%$ dari tahun sebelumnya (Dewi \& Anita, 2015). Gagal Ginjal Kronik tidak memberikan gejala yang khas sehingga penderita sering terlambat ditangani. Pasien didiagnosa pertama kali penuruna fungsi ginjal mencapai lebih dari $50 \%$ dari ginjal normal, sehingga berdampak pada suatu komplikasi kardiovaskuler (Kemenkes RI dalam Winarti, Aini \& Susilo, 2017).

Menurut USRDS di Amerika Serikat lebih dari $65 \%$ pasien dengan gagal ginjal kronis menjalani hemodialisis. Berdasarkan IRR Indonesia melaksanakan pelayanan kesehatan rutin hemodialisa sejak tahun 2007 sebanyak 140.972 ribu pasien dan bertambah mencapai 694.007 ribu di tahun 2013 (IRR, 2013, Budiono, 2016).

Di Indonesia penderita gagal ginjal kronis berdasarkan Riskesdas pada tahun 2013, prevalensi gagal ginjal kronis $0,2 \%$ dari penduduk Indonesia. Hanya $60 \%$ dari pasien gagal ginjal kronis tersebut yang menjalani terapi dialisis. Di provinsi Sumatera Utara penderita gagal ginjal kronis mencapai 6 ribu orang sedangkan yang terdata hanya 3 ribu orang (PERNEFRI, 2013).

Ginjal berfungsi untuk membuang zatzat metabolik yang beracun dan cairan yang berlebihan dari tubuh, bila terjadi penurunan fungsi ginjal maka akan terjadi gangguan pada metabolisme tubuh yang mengakibatkan ginjal tidak dapat menjaga kelangsungan hidup penderitanya sehingga memerlukan terapi hemodialisa (cuci darah) sebagai terapi pengganti fungsi ginjal (Lestari dan Nurmala, 2015).
Hemodialisis (cuci darah) merupakan suatu terapi yang menggunakan mesin sebagai pengganti ginjal di luar tubuh yang berfungsi memfiltrasi darah agar darah terpisah dari sisa metabolisme tubuh dan hemodialisis dapat mencegah kematian (Smeltzer, 2013). Darah dikeluarkan dari tubuh dan masuk ke dalam mesin dialiser untuk dibersihkan didalam dialiser (ginjal buatan) kemudian dialirkan kembali ke dalam tubuh (Alam \& Hadibroto, 2009).

Pasien gagal ginjal kronis menjalani hemodialisis seumur hidupnya dengan frekwensi 2-3 kali dalam seminggu dengan lama hemodialisis 4-5 jam untuk 1 kali kunjungan. Pasien mengkonsumsi obat pengendali tekanan darah, membatasi cairan, makan makanan tinggi kalori rendah protein, menghindari mengkonsumsi buah-buahan, melakukan aktivitas sesuai toleransi dan istirahat yang cukup serta mengendalikan emosi atau menghindari stress (Smeltzer, 2013).

Hemodialisis yang efektif dicapai 1012 jam perminggunya. Selain itu lama hemodialisis kecepatan aliran darah, akses vascular yang baik, patuh terhadap diet cairan, garam dan menghindari buah-buahan menjadikan terapi dialysis efektif (Rohimi, 2016).

Salah satu masalah besar yang memberikan kontribusi kegagalan dalam proses hemodialisis adalah masalah ketidakpatuhan. Pasien dianjurkan mengikuti aturan diet, merubah gaya hidup, mengkonsumsi obat-obatan yang direkomendasikan pemberi pelayanan kesehatan dan teratur melakukan terapi hemodialisis. Ketidakpatuhan yang dilakukan pasien memberikan dampak buruk terhadap kesehatan pasien tersebut (Syamsiah, 2011).

Diperlukan kepatuhan dalam proses penatalaksanaan hemodialisis untuk mencapai kualitas hidup yang lebih baik (Anissa, 2016). Faktor yang mempengaruhi pasien dalam kepatuhan menjalani hemodialisis adalah dukungan keluarga (Sunarni, 2009; Rostanti, Bawotong, dan Onibala, 2016), Motivasi (Lestari dan Nurmala, 2015). usia (Syamsiah, 
2011), akses pelayanan dalam hal jarak (Budiono, 2016), pendapatan dan dukungan keularga (Syamsiah, 2011), motivasi (Izzati dan Nurmala, 2016).

Ketidakpatuhan menimbulkan komplikasi kegawatan pada pasien gagal ginjal kronis seperti hiperkalemia dan edema pada tubuh. Komplikasi tersebut akan menyebabkan penurunan fungsi fisik, nyeri pada tubuh, perubahan persepsi dan proses fikir serta mengalami ketidaknyamana sehingga mempengaruhi aktifitas pasien dalam kehidupan sehari-hari, berdampak pada kualitas hidup pasien (Suhud, 2009 dalam Hendiani \& Wahyuni, 2012).

Berdasarkan survey awal yang dilakukan pada Rumah Sakit Umum Daerah Gunungsitoli Nias dalam 2 tahun terakhir pasien gagal ginjal yang menjalani hemodialisis meningkat. Tahun 2016 rata-rata perbulannya 32 orang dan 2017 meningkat menjadi 48 orang per bulan. Rata-rata kunjungan tiap bulannya tidak sesuai dengan jadwal yang ditentukan, dengan jadwal ratarata 2 kali dalam seminggu namun datang hanya 1 kali dalam seminggu. Pasien kembali dalam keadaan kesehatan menurun seperti penurunan fungsi fisik, penurunan kesadaran dan peningkatan ureum dan kreatinin dalam darah yang ekstrim.

Hasil wawancara sebanyak 10 pasien rata-rata pasien tidak patuh menjalani hemodialisis, 3 orang pasien mengatakan karena jarak ke rumah sakit sangat jauh karena tinggal di lain kabupaten sehingga mengeluarkan biaya yang besar dan 2 orang dikarenakan kondisi ekonomi dan 5 orang pasien mengatakan karena merasa tidak akan sembuh dan keluarga tidak sempat menemani ke rumah sakit.

Tahun 2015 jumlah kunjungan ratarata perbulannya 160 kunjungan dan tahun 2017 meningkat menjadi 257 kunjungan, hingga bulan Maret 2017 kunjungan menjadi 384 kunjungan dengan jumalah pasien 53 orang. Tujuan penelitian ini adalah untuk mengetahui faktor - faktor yang mempengaruhi kepatuhan pasien Gagal ginjal kronis yang menjalani hemodialisis di RSUD Gunungsitoli Nias.

\section{METODE PENELITIAN}

Penelitian ini menggunakan desain analitik komparatif dengan rancangan penelitian crossectional study. Populasi dalam penelitian ini adalah pasien Gagal Ginjal Kronis yang menjalani terapi hemodialisis di Unit Hemodialisis Rumah Sakit Umum Daerah Gunungsitoli Nias dengan teknik pengambilan data menggunakan teknik accidental sampling dengan jumlah sampel didapatkan sebanyak 48 orang. Alat pengumpulan data menggunakan instrumen kuesioner dimana variabel dukungan keluarga nilai Crombach Alfa 0,971 dan variabel motivasi dengan nilai Crombach Alfa 0,959. Uji Satatistik menggunakan Person Chi-Square Test.

\section{HASIL PENELITIAN \\ Analisis Univariat}

Tabel 1.

Distribusi Frekuensi Dan Persentase berdasarkan Karakteristik jenis kelamin, pekerjaan, Usia, Pendapatan, Jarak, Motivasi, Dukungan Keluarga Dan Kepatuhan Responden Yang Menjalani Hemodialisis Di RSUD Gunungsitoli Nias Tahun 2017 ( $n=48$ ).

\begin{tabular}{llcc}
\hline $\begin{array}{l}\text { Karakteris } \\
\text { tik }\end{array}$ & Kategori & f & \% \\
\hline Jenis & Laki-laki & 38 & 79.2 \\
Kelamin & Perempuan & 10 & 20.8 \\
\hline Pekerjaan & Tidak & 2 & 4.2 \\
& berkerja & & \\
& TNI/POLRI & 1 & 2.1 \\
& Petani & 4 & 8.3 \\
& Ibu rumah & 2 & 4.2 \\
& tangga & & \\
& Wiraswasta & 10 & 20.8 \\
& PNS & 29 & 60.4 \\
& Tidak & 2 & 4.2 \\
& berkerja & & \\
\hline Usia & $\leq 30$ Tahun & 3 & 6.3 \\
& 31-40 Tahun & 30 & 62.5 \\
& $\geq 41$ Tahun & 15 & 31.2 \\
\hline Pendapatan & Rendah & 13 & 27.1 \\
& Sedang & 15 & 31.2 \\
& Tinggi & 20 & 41.7 \\
\hline Jarak & $\leq 3$ Km & 15 & 31.2 \\
& $\geq 3$ Km & 33 & 68.8 \\
\hline Motivasi & Tinggi & 33 & 68.8 \\
& Rendah & 15 & 31.2 \\
\hline Dukungan & Baik & 24 & 50 \\
Keluarga & Cukup & 15 & 31.2 \\
& Kurang & 9 & 18.8 \\
\hline Kepatuhan & Patuh & 32 & 66.7 \\
& TIdak Patuh & 16 & 33.3 \\
\hline & & & \\
\hline
\end{tabular}




\section{Analisis Bivariat}

Tabel 2.

Tabulasi Silang Dan Uji Statistik Chi-Square Faktor Usia Mempengaruhi Kepatuhan Pasien Hemodialisis Di RSUD Gunungsitoli Nias tahun 2017.

\begin{tabular}{|c|c|c|c|c|c|c|c|}
\hline \multirow[t]{2}{*}{ Usia } & \multicolumn{6}{|c|}{ Kepatuhan } & \multirow{2}{*}{$\begin{array}{l}\text { P- } \\
\text { val } \\
\text { ue }\end{array}$} \\
\hline & $\begin{array}{l}\text { Pa } \\
\text { tuh }\end{array}$ & $\%$ & $\begin{array}{c}\text { Ti } \\
\text { dak } \\
\text { Pa } \\
\text { tuh }\end{array}$ & $\%$ & $\begin{array}{c}T \\
\text { ot } \\
\text { al }\end{array}$ & $\%$ & \\
\hline$\leq 30$ Tahun & 2 & 4.2 & 1 & 2.1 & 3 & 6.3 & \\
\hline 31-40 Tahun & 22 & 45.8 & 8 & 16.7 & 30 & 62.5 & 0,4 \\
\hline$\geq 41$ Tahun & 8 & 16.7 & 7 & 15.4 & 15 & 31.2 & 07 \\
\hline Total & 32 & 66.7 & 16 & 33.3 & 48 & 100 & \\
\hline
\end{tabular}

Tabel 3.

Tabulasi Silang Dan Uji Statistik Chi- Square

Faktor Pendapatan Mempengaruhi Kepatuhan

Pasien Hemodialisis Di RSUD Gunungsitoli

Nias tahun 2017.

\begin{tabular}{cccccccc}
\hline $\begin{array}{c}\text { Pendapa } \\
\text { tan }\end{array}$ & $\begin{array}{c}\text { Pat } \\
\text { uh }\end{array}$ & $\begin{array}{c}\text { Kepatuhan } \\
\text { Tid } \\
\text { ak }\end{array}$ & $\begin{array}{c}\text { \% } \\
\text { Pat } \\
\text { uh }\end{array}$ & $\begin{array}{c}\text { Tot } \\
\text { al }\end{array}$ & $\begin{array}{c}\text { P- } \\
\text { value }\end{array}$ \\
& & & & & & \\
\hline Rendah & 4 & 8.3 & 9 & 18.8 & 13 & 27.1 & \\
Sedang & 9 & 18.8 & 6 & 12.5 & 15 & 31.2 & 0,001 \\
Tinggi & 19 & 39.6 & 1 & 2.1 & 20 & 41.7 & \\
\hline Total & $\mathbf{3 2}$ & $\mathbf{6 6 . 7}$ & $\mathbf{1 6}$ & $\mathbf{3 3 . 3}$ & $\mathbf{4 8}$ & $\mathbf{1 0 0}$ & \\
\hline
\end{tabular}

Tabel 4.

Tabulasi Silang Dan Uji Statistik Chi-Square

Faktor Jarak Mempengaruhi Kepatuhan Pasien

Hemodialisis Di RSUD Gunungsitoli Nias tahun 2017.

\begin{tabular}{|c|c|c|c|c|c|c|c|}
\hline \multirow[t]{2}{*}{ Jarak } & \multicolumn{6}{|c|}{ Kepatuhan } & \multirow{2}{*}{$\begin{array}{c}\text { P- } \\
\text { value }\end{array}$} \\
\hline & $\begin{array}{c}\text { Pat } \\
\text { uh }\end{array}$ & $\%$ & $\begin{array}{c}\text { Tid } \\
\text { ak } \\
\text { Pat } \\
\text { uh }\end{array}$ & $\%$ & $\begin{array}{c}\text { T } \\
\text { ot } \\
\text { al }\end{array}$ & $\%$ & \\
\hline$\leq 3 \mathrm{Km}$ & 9 & 18.8 & 6 & 12.5 & 15 & 31.2 & \multirow{3}{*}{0,509} \\
\hline$\geq 3 \mathrm{Km}$ & 23 & 47.9 & 10 & 20.8 & 33 & 68.8 & \\
\hline Total & 32 & 66.7 & 16 & 33.3 & 48 & 100 & \\
\hline
\end{tabular}

Tabel 5.

Tabulasi Silang Dan Uji Statistik Chi-Square Faktor Motivasi Mempengaruhi Kepatuhan Pasien Hemodialisis Di RSUD Gunungsitoli Nias tahun 2017.

\begin{tabular}{|c|c|c|c|c|c|c|c|}
\hline \multirow{2}{*}{$\begin{array}{l}\text { Motiva } \\
\text { si }\end{array}$} & \multicolumn{6}{|c|}{ Kepatuhan } & \multirow{2}{*}{$\begin{array}{c}P- \\
\text { value }\end{array}$} \\
\hline & $\begin{array}{l}\text { Pat } \\
\text { uh }\end{array}$ & $\%$ & $\begin{array}{c}\text { Tid } \\
\text { ak } \\
\text { Pat } \\
\text { uh }\end{array}$ & $\%$ & $\begin{array}{l}T \\
\text { ot } \\
\text { al }\end{array}$ & $\%$ & \\
\hline Tinggi & 24 & 50 & 9 & 18.8 & 33 & 68.8 & \\
\hline Rendah & 8 & 16.7 & 7 & 14.5 & 15 & 31.2 & 0,186 \\
\hline Total & 32 & 66.7 & 16 & 33.3 & 48 & 100 & \\
\hline
\end{tabular}

Tabel 6.

Tabulasi Silang Dan Uji Statistik Chi-Square Faktor Dukungan Keluarga Mempengaruhi Kepatuhan Pasien Hemodialisis Di RSUD Gunungsitoli Nias tahun 2017.

\begin{tabular}{|c|c|c|c|c|c|c|c|}
\hline \multirow{2}{*}{$\begin{array}{c}\text { Dukun } \\
\text { gan } \\
\text { Keluar } \\
\text { ga }\end{array}$} & \multicolumn{6}{|c|}{ Kepatuhan } & \multirow{2}{*}{$\begin{array}{c}\text { P- } \\
\text { val } \\
\text { ue }\end{array}$} \\
\hline & $\begin{array}{l}\text { Pat } \\
\text { uh }\end{array}$ & $\%$ & $\begin{array}{c}\mathbf{T i} \\
\text { dak } \\
\text { Pa } \\
\text { tuh } \\
\end{array}$ & $\%$ & $\begin{array}{c}\text { Tot } \\
\text { al }\end{array}$ & $\%$ & \\
\hline Baik & 23 & 47.9 & 1 & 2.1 & 24 & 50 & \\
\hline Cukup & 7 & 14.6 & 8 & 16.7 & 15 & 31.2 & 0,0 \\
\hline Kurang & 2 & 4.2 & 7 & 14.5 & 9 & 18.8 & 00 \\
\hline Total & 32 & 66.7 & 16 & 33.3 & 48 & 100 & \\
\hline
\end{tabular}

\section{PEMBAHASAN}

Faktor Usia Mempengaruhi Kepatuhan Pasien Gagal Ginjal Menjalani Hemodialisis

Berdasarkan tabel 2 menunjukkan uji chi-square faktor usia tidak mempengaruhi kepatuhan dengan $p$ value 0,407 ( $p>0,05)$. Hasil penelitian ini menunjukkan usia responden mayoritas usia produktif dimana usia ini merupakan usia yang masih aktif dalam bekerja, yang dimungkinkan pasien mengalami kesulitan dalam mengatur jadwal bekerja dengan kunjungan untuk terapi hemodialisis.

Sejalan dengan penelitian Hakiki \& Ruhyana (2015) bahwa tidak ada hubungan usia dengan kepatuhan cairan dan nutrisi di RS PKU Muhammadiyah Yogyakarta Akan tetapi, hasil penelitian ini tidak sejalan dengan Syamsiah (2011) dimana faktor usia berhubungan dengan kepatuhan Pasien CKD Yang Menjalani Hemodialisa di RSPAU Dr. Esnawan Antariksa Halim Perdana Kusuma Jakarta. Pada penelitian tersebut, usia yang ditetapkan adalah $\geq 65$ tahun yang menunjukkan kepatuhan, akan tetapi pada penelitian ini usia mayoritas $\leq 65$ tahun yang artinya usia tersebut cenderung menunjukkan peluang ketidakpatuhan akan terapi hemodialisis. Penelitian yang sejalan dengan Syamsiah (2011) yaitu Izzati \& Annisa (2016) 
menyimpulkan ada hubungan yang bermakna antara umur dengan kepatuhan menjalani hemodialisis.

Menurut Siagian (2001) dalam Syamsiah (2011) menjelaskan bahwa usia berhubungan sangat erat dengan kedewasaan seseorang, yang maknanya semakin bertambah usia maka semakin dewasa dan matang dalam hal bersikap, emosional maupun spiritualnya sehingga semakin meningkatkan kemampuan seseorang tersebut dalam mengambil suatu keputusan, mampu berfikir rasional, mengontrol emosional, toleransi akan pendapat porang lain serta mampu berfikir kritis dalam menyelesaikan masalah kesehatannya. Kammerer, Garry, Hartigan, Carter \& Erlich (2007) menyatakan bahwa usia merupakan bagian dari komponen faktor individu yang dapat mempengaruhi individu tersebut.

\section{Faktor Pendapatan Mempengaruhi Kepatuhan Pasien Gagal Ginjal Menjalani Hemodialisa}

Berdasarkan tabel 3 menunjukkan uji chi-square faktor pendapatan mempengaruhi kepatuhan dengan $p$ value $0,001 \quad(\mathrm{p}<0,05)$. Diperoleh data bahwa responden dalam penelitian ini mayoritas Pegawai Negeri Sipil (PNS) yang mana pendapatan mereka telah terstandar pengajian oleh negara. Pasien yang bekerja di lingkungan pemerintahan telah mendapat jaminan kesehatan berupa BPJS yang menjamin masalah kesehatan seperti terapi hemodialisis. Walaupun demikian menurut Budiono (2016) bahwa selain biaya terapi hemodialisis yang sudah dijamin oleh BPJS, pasien harus mengeluarkan dana untuk biaya obat-obatan tambahan, transportasi, pembelian makanan bahkan membiayai anggota keluarga yang mendampingi ketika menjalani proses hemodialisis.

Berdasarkan Sunaryo, 2004; Butar, 2011; Syamsiah (2011) menjelaskan seseorang yang memiliki pendapatan atau ekonomi yang berkecukupan maka seseorang itu dapat memenuhi segala kebutuhannya dan bila pendapatannya rendah maka akan mengalami hambatan dalam memenuhi kebutuhan hidupnya.

Hasil penelitian ini sejalan dengan penelitian Budiono (2016) bahwa ada pengaruh yang bermakna antara pendapatan (ekonomi) dengan kepatuhan menjalani hemodialisis.

\section{Pengaruh Jarak Mempengaruhi Kepatuhan Pasien Gagal Ginjal Menjalani Hemodialisis}

Berdasarkan tabel 4 menunjukkan uji chi-square faktor jarak tidak mempengaruhi kepatuhan dengan $p$ value 0,509 ( $>00,05)$. Penelitian ini menunjukkan jarak tempat tinggal pasien mayoritas $\geq 3 \mathrm{Km}$ dimana hanya satu rumah sakit saja di kota GunungSitoli Nias yang tersedia layanan hemodialisis bagi pasien yang mengalami gagal ginjal kronis tahap akhir. Pasien cenderung berasal dari berbagai kabupaten disekitar pulau Nias dengan jarak tempuh berjam-jam bahkan melewati pulau-pulau. Akan tetapi, jarak tidak memberikan efek signifikan bahwa terhadap kepatuhan.

Hasil penelitian ini sejalan dengan Syamsiah (2011) bahwa tidak ada hubungan antara akses pelayanan kesehatan dengan kepatuhan pasien gagal ginjal ronis yang menjalani hemodialisis dimana OR 1.206 menunjukkan akses yang terjangkau ke pelayanan kesehatan memiliki kesempatan lebih patuh dibanding dengan akses yang sulit dijangkau.

Berdasarkan Syamsiah (2011) bahwa faktor jarak merupakan bagian dari faktor pemungkin (enabling factors) yang berkaitan kemudahan akses pelayanan kesehatan. Selain itu, Menurut Fatmawati, Supriati \& Hidayah (2014) bahwa walaupun pasien sudah patuh, yang menjadi penyebab pasien tidak mejalani terapi hemodialisis dapat dikarenakan pasien merasa nyaman dengan keadaan tubuhnya sehingga pasien menunda pergi disebabkan jarak yang jauh dari tempat tinggal.

\section{Pengaruh Motivasi Mempengaruhi Kepatuhan Pasien Gagal Ginjal Menjalani Hemodialisis}

Berdasarkan tabel 6 menunjukkan bahwa uji chi-square menunjukkan faktor motivasi tidak mempengaruhi kepatuhan dengan $p$ value 0,186 ( $\mathrm{p}>0,05)$. Berdasarkan analisa univariat menunjukkan mayoritas motivasi pasien dengan kategori tinggi dengan kepatuhan dalam kategori tinggi, artinya motivasi tinggi akan menunjukkan kepatuhan. Perbedaan hasil penelitian ini dapat dimungkinkan jarak yang jauh dari layanan 
kesehatan, pendapatan yang tinggi dan mendapat dukungan keluarga yang baik sehingga motivasi pasien tidak sekuat bila mereka tersebut tidak dimilikinya, hal ini dimungkinkan bahwa pasien merasa nyaman dengan kondisinya dan terikat dengan pekerjaan.

Menurut (Azwar, 1996) dalam Budiono (2016) motivasi merupakan suatu aksi, dorongan ataupun pendukung yang dimiliki seseorang untuk melakukan sesuatu yang telah direncanakan untuk pencapaian target yang telah dirancang. Pernyataan tersebut sejalan pendapat Kammerer, Garry, Hartigan, Carter \& Erlich (2007) bahwa yang membuktikan motivasi memiliki hubungan yang kuat dengan kepatuhan. Penelitian Syamsiah (2011) berbeda dengan penelitian ini bahwa ada hubungan motivasi dengan kepatuhan pasien CKD yang menjalani hemodialisis dengan odds ratio (OR) 2,248 yang maknanya semakin tinggi motivasi maka seseorang lebih patuh sebesar 2,248 kali dibandingkan seseorang yang memiliki motivasi rendah.

Sejalan dengan penelitian Syamsiah (2011) bahwa Izzati dan Annisha, (2015) menyimpulkan ada pengaruh yang bermakna antara motivasi dengan kepatuhan menjalani hemodialisis dengan nilai $(\mathrm{p}=0,045)$. Demikian juga penelitian Dani, Utami \& Bayhakki (2015) terdapat hubungan yang signifikan antara motivasi dengan kepatuhan pasien GGK untuk menjalani hemodialisis dengan $p$-value $(0,004<0,05)$. Selain itu, Lestari \& Nurmala (2015) juga berbeda dengan penelitian ini yaitu ada hubungan motivasi dengan kepatuhan menjalani hemodialisa pada pasien gagal ginjal kronik dengan $\mathrm{p}$ value $0,001(\mathrm{p}<0,05)$.

\section{Pengaruh Dukungan Keluarga Mempengaruhi Kepatuhan Pasien Gagal Ginjal Menjalani Hemodialisis}

Berdasarkan tabel 7 menunjukkan bahwa uji chi-square menunjukkan dukungan keluarga mempengaruhi kepatuhan dengan $p$ value $0,000 \quad(\mathrm{p}<0,05)$. Hal ini disebabkan beberapa aspek dukungan terpenuhi oleh pasien seperti faktor pekerjaan yang memadai, usia yang masih produktif dan dukungan keluarga yang baik. Hasil penelitian ini didukung Fatmawati, Supriati \& Hidayah (2014) menyatakan terdapat hubungan antara dukungan keluarga dengan kepatuhan pasien GGK dalam menjalani hemodialisa dengan nilai $p$ value 0,001 dan nilai odd ratio (OR) sebesar 23,125, yang maknanya dukungan keluarga mempengaruhi 23,125 kali kepatuhan pasien dalam menjalani hemodialisa.

Selain itu, Winarti, Aini \& Susilo (2017) menunjukkan bahwa ada hubungan dukungan keluarga dengan kepatuhan pasien gagal ginjal kronik yang menjalani terapi hemodialisa di RSUD Tugurejo Semarang. Hasil penelitian ini sejalan dengan hasil penelitian Rostanti, Bawotong, Onnibala (2016) yang menyimpulkan bahwa faktor dukungan keluarga berhubungan dengan kepatuhan menjalani hemodialisis dengan nilai $p$ value $0.000(\mathrm{p}<0.05)$.

Dukungan keluarga adalah faktor yang penunjang yang paling mempengaruhi ketidakpatuhan pasien dalam perawatan hemodialisa. Pasien tidak bisa melakukan terapi hemodialisa sendiri memerlukan pendampingan ke pelayanan kesehatan untuk terapi hemodialisa dan melakukan kontrol ke dokter. Tanpa dukungan keluarga tentunya sulit menjalani program terapi hemodialisa sesuai jadwal yang telah ditentukan (Sunarni, 2009).

Menurut Fridman (2010) dukungan keluarga adalah suatu respon yang ditunjukkan dengan menerima keadaan anggota keluarga dari aspek dukungan informasional, dukungan penilaian, dukungan instrumental dan dukungan emosional, sehingga dapat diartikan dukunan keluarga merupakan keterikatan hubungan interpersonal yang meliputi sikap, tindakan dan penerimaan terhadap anggota keluarga, sehingga anggota keluarga merasakan perhatian dari anggota keluarga lainnya. Berdasarkan Hendiani \& Wahyuni (2012) perawatan kesehatan yang diberikan berdasarkan kemampuan keluarga akan mempengaruhi status kesehatan keluarga, yang artinya keluarga adalah sumber dukungan yang paling penting dalam memelihara kesehatan keluarga.

\section{KESIMPULAN}

Berdasarkan hasil penelitian dapat disimpulkan faktor usia, jarak dan motivasi tidak mempengaruhi kepatuhan pasien gagal ginjal kronis yang menjalani hemodialisis di RSUD Gunungsitoli Nias dan faktor pendapatan (Ekonomi) dan dukungan keluarga 
mempengaruhi kepatuhan pasien gagal ginjal kronis yang menjalani hemodialisis di RSUD Gunungsitoli Nias.

Hasil penelitian ini diharapkan bagi responden untuk meningkatkan kepatuhan menjalani hemodialisis agar memiliki kualitas hidup yang baik. Bagi keluarga dan petugas kesehatan dapat memberikan dukungan kepada anggota keluarga yang menjalani hemodialisa danselalu mendampingi serta memberi semangat dalam menjalani hemodialisis.

\section{REFERENSI}

Alam \& Hadibroto. (2009). Gagal Ginjal. Jakarta : PT Gramedia.

Annisa, H. (2016). Hubungan Kepatuhan Diet Dan Asupan Kalium Dengan Kadar Kalium Pada Pasien Gagal Ginjal Kronik Yang Menjalani Hemodialisa Rawat Jalan Di RSUD Kabupaten Sukoharjo. Diakses dari http://eprints.ums.ac.id/40578/29/hala man\%20depan.pdf

Budiono, A. (2016). Hubungan Dukungan Sosial Dengan Kepatuhan Menjalani Hemodialisis Rutin Pada Pasien Gagal Ginjal Kronik Di RSUD Salatiga. Skripsi.

Dani, R, E, Utami, G.T \& Bayhakki. (2015). Hubungan Motivasi, Harapan, Dan Dukungan Petugas Kesehatanterhadap Kepatuhan Pasien Gagal Ginjal Kronik untuk Menjalani Hemodialisis. JOM Vol 2 No 2, Oktober 2015.

Dewi, S.P \& Anita, D.C. (2015). Hubungan Lamanya Hemodialisa dengan Kualitas Hidup Pasien Gagal Ginjal di RS PKU Muhammadiyah Yogyakarta Skripsi. Yogyakarta: STIKES Aisyiyah dari http://digilib.unisayogya.ac.id/234/

Fatmawati, E., A, Supriati, E \& Hidayah, M.,N. (2014). Hubungan Dukungan Keluarga Dan Sikap Perawat Dengan Kepatuhan Pasien Gagal Ginjal Kronik Dalam Menjalani Terapi Hemodialisa Di RSUD Dr. Soedarso Pontianak.Skripsi.

Friedman, M. (2010). Buku Ajar Keperawatan keluarga : Riset, Teori, dan Praktek. Edisi ke-5. Jakarta: EGC.

Hendiani, D \& Wahyuni. (2012). Hubungan Dukungan Keluarga Dengan Kepatuhan Lansia Dalam Mengikuti
Posyandu Lansia Di Posyandu Lansia Jetis Desa Krajan Kecamatan Weru Kabupaten Sukoharjo. Jurnal STIKES. Volume9.Hal 49-50. http://digilib.unimus.ac.id/files/disk1/1 45/ jtptunimus-gdl-dewimarliy-72405-daftarp-a.pdf

Izzati, W \& Annisa, F. (2016). Faktor-Faktor Yang Berhubungan Dengan Kepatuhan Pasien Yang Menjalani Hemodialisis Di Ruang Hemodialisa Di RSUD Dr. Achmad Mochtar Bukittinggi Tahun 2015. Afiyah. Vol. 3, No. I, Bulan Januari, Tahun 2016.

Kammerer J., Garry G., Hartigan M., Carter B., Erlich L. (2007). Adherence in Patients On Dialysis: Strategies for Succes. Nephrology Nursing Journal. Vol 34 (5). 479-485.

Lestari, D. A \& Nurmala, E (2015). Hubungan Motivasi Pasien dengan Kepatuhan Menjalani Hemodialisa pada Pasien Gagal Ginjal Kronik di Rumah Sakit Umum Daerah Kraton Pekalongan. Skripsi. dari http://www.eskripsi.stikesmuh-

pkj.ac.id/eskripsi/index.php?p=fstrea m\&fid $=1076 \& b i d=1138 \backslash$

Pernefri (2013). $5^{\text {th }}$ Report of Indonesian Renal Registry. http://www.pernefriinasn.org//4th\%2 OAnnual\%20Report\%200f\%20IRR\%20 2011.pdf

Rohimi. (2016). Kepatuhan Pasien Gagal Ginjal Kronis (Ggk) Dalam Mempertahankan Berat Badan Diantara Dua Waktu Dialisis (Inter Dialysis Weight Gain = Idwg) Di Ruang Hemodialisa Rs Sari Asih Serang" http://stikes.wdh.ac.id/media/pdf/jurna 1_ns._riris_andriati_s.kep., m.kep.pdf. Rostanti, A., Bawotong, J \& Onibala, F. (2016). Faktor Faktor Yang Berhubungan Dengan Kepatuhan Menjalani Terapi Hemodialisa Pada Penyakit Ginjal Kronik Di Ruangan Dahlia Dan Melati RSUP. Prof. Dr. R. D Kandou Manado, E-Journal Keperawatan (E-Kp) Volume 4 Nomor 2, Agustus 2016. 
Smeltzer. (2013). Keperawatan Medikal Bedah. Edisi 8 Volume 2. Jakarta : Penerbit Buku Kedokteran EGC.

Sunarni. (2009). Hubungan Antara Dukungan Keluarga Dengan Kepatuhan Menjalani Hemodialisa pada Pasien GGK di RSUD Dr. Moewardi Surakarta, Skripsi, Fakultas Ilmu Kesehatan, Universitas Muhammadiyah Surakarta, Surakarta : 1 http://eprints.ums.ac.id/18464/9/08.

Syamsiah, N. (2011). Faktor-Faktor yang Berhubungan dengan Kepatuhan Pasien CKD yang Menjalani Hemodialisa Di RSPAU Dr. Esnawan Antariksa Halim Perdana Kusuma Jakarta. Universitas Indonesia. Fakultas Ilmu Keperawatan. Program Studi Magister Keperawatan. Kekhususan Keperawatan Medikal Bedah. Jakarta. (Tesis).

Winarti, R., Aini, D.N., Susilo, J. (2017). Faktor-Faktor Yang Berhubungan Dengan Kepatuhan Pasien Gagal Ginjal Kronik Yang Menjalani Hemodialisa Di RSUD Tugurejo Semarang. Skripsi. 